Człowiek chory i umierający. Możliwości wsparcia i formy pomocy, red. J. Stala, Kraków 2014, Wydawnictwo Naukowe UPJPII, s. 61-69. http://dx.doi.org/10.15633/9788374384117.05

Andrzej Grudziński*

Akademia Ignatianum w Krakowie

\title{
LUDZIE STARZY W OBLICZU WSPÓŁCZESNYCH PRZEMIAN
}

Minione epoki charakteryzowały się dualizmem postaw wobec ludzi starych. Ich miejsce i prestiż były zależne od ustroju, struktury społecznej, priorytetów kulturowych, modelu i funkcji rodziny oraz miejsca w hierarchii społecznej wypracowanego przez całe życie. Symptomatyczne jest jednak to, że w każdej z epok ludzie bali się starości i żałowali utraconej młodości. Współcześnie tematyka związana ze starzeniem się i starością wywołuje wiele emocji. Ten etap ludzkiego życia coraz częściej łączy się z lękiem, obawą, brakiem pozytywnego obrazu starości i chęcią ucieczki od niej za wszelką cenę.

\section{Zarys historii starości}

Już w czasach prehistorycznych ludzie przejawiali postawy niechęci wobec starości. Dla pierwotnych cywilizacji, które żyły w uciążliwych warunkach i musiały zmagać się z siłami natury oraz walczyć o pożywienie ludzie starzy byli ciężarem. Jako jednostki słabsze, chorowite i niepełnowartościowe zostali zepchnięci na margines oraz pozbawieni pozycji w gromadzie, mogąc jedynie oczekiwać na śmierć. Ludom pierwotnym nieobce były także zachowania polegające na fizycznym eliminowaniu z gromady ludzi starych. Z czasem pozycja osób w podeszłym wieku uległa zmianie. W dużej mierze wpływ na to miało pojawienie się ognia i początki rolnictwa. Dzięki temu starzy ludzie mieli pewne obowiązki: pomagali

* ANDRZEJ GRUDZIŃSKI - doktor nauk humanistycznych w zakresie pedagogiki (Katolicki Uniwersytet Lubelski Jana Pawła II), adiunkt w Instytucie Nauk o Wychowaniu Akademii Ignatianum. Uczestnik i współorganizator konferencji naukowych w Polsce i zagranicą. Autor licznych publikacji naukowych krajowych i zagranicznych z zakresu pedagogiki i pracy socjalnej. 
kobietom w podtrzymywaniu ognia, dozorowali domowe ogniska, dbali o bezpieczeństwo zgromadzonych zapasów żywności ${ }^{1}$.

Dwie tendencje w postrzeganiu ludzi starych widoczne były także w czasach starożytnych. Przedstawiciele jednej z nich - między innymi Platon i Cyceron postrzegali wiek sędziwy jako czas mądrości i doświadczenia, który należy otoczyć szacunkiem i czcią. Z kolei reprezentujący przeciwstawną tendencję Arystoteles traktował starość jako upośledzenie charakteryzujące się marudnością, kłótliwością, skąpstwem, tchórzliwością i wyrachowaniem. Postulował przy tym eliminowanie ludzi starych z życia publicznego ${ }^{2}$.

W Sparcie osoby zaawansowane wiekiem pełniły funkcje przywódcze. W radzie starców, czyli geruzji zasiadało dwudziestu ośmiu najstarszych obywateli zwanych gerontami, którzy sprawowali najwyższą władzę ustawodawczą ${ }^{3}$. Dualizm postaw wobec starości można zauważyć także w Cesarstwie Rzymskim. O ile starcy cieszyli się zaufaniem i powagą w okresach trwania republiki, o tyle w czasach skupienia władzy w rękach cesarza ich autorytet gwałtowanie malał, zaś starość stawała się symbolem słabości i cierpienia. Chrześcijaństwo od początku otoczyło starców opieką (podobnie jak ubogich, chorych, niepełnosprawnych), traktując ich jako ludzi potrzebujących wsparcia i pomocy. Jednocześnie przyczyn starości doszukiwano się w karze za grzechy, których symbolem była brzydota zniszczonego wiekiem ciała. Uważano przy tym, że fizyczna ułomność powinna przypominać starcom o ulotności doczesnego życia, skłaniając do aktywności religijnej i starań o zbawienie duszy.

We wczesnym średniowieczu seniorzy odznaczali się niską pozycję społeczną. Bogatsi spośród nich mogli wstąpić do klasztoru, który pełnił rolę swoistego przedsionka łączącego życie doczesne z wiecznym. Osoby niżej urodzone, bez pomocy rodziny stawały się biedakami, co było równoznaczne z zaprzestaniem jakiejkolwiek działalności społecznej, czy zawodowej. ${ }^{5}$ Z kolei ludzie renesansu jako epoki ceniącej piękno ciała, urodę życia i uroki młodości do starości podchodzili z niechęcią i pogardą. Humaniści epoki odrodzenia uważali, iż starość, którą utożsamiali z cierpieniem, pozbawia człowieka siły i sprawności umysłowej. Z upływem kolejnych lat wiek podeszły został utożsamiony z biedą i chorobami, pomimo nierzadkich przypadków piastowania przez seniorów najważniejszych stanowisk w państwie.

\footnotetext{
1 J. Nowicki, Historyczne uwarunkowania postrzegania roli człowieka starego w społeczeństwie, w: Wybrane problemy osób starszych, red. A. Nowicka, Kraków 2008, s. 44-45.

2 O. Czerniawska, Starość wczoraj, dziś i jutro, w: Ludzie starsi w trzecim tysiącleciu. Szanse - nadziejepotrzeby, red. W. Wnuk, Wrocław 2002, s. 12-13.

3 Z. Szarota, Gerontologia społeczna i oświatowa. Zarys problematyki, Kraków 2004, s. 6.

4 G. Minois, Historia starości. Od antyku do renesansu, Warszawa-Gdańsk 1995, s. 100.

5 J. Kracik, Być starym dawno temu, „Kontrapunkt” 39/40 (2000) nr 1/2, s. 1.
} 
W XVIII wieku w Europie zapoczątkowano wypłacanie emerytur, z których jako pierwsi zaczęli korzystać wojskowi. W miarę upowszechniania się w wieku XIX systemu emerytalnego ludzie starzy przestali żyć na wyłączny koszt rodziny6

Na przestrzeni wieków ukształtowały się dwa podejścia do ludzi starych i starości. Pierwszym z nich jest gerontokracja (z języka greckiego géron, gérontos starość; krátos - władza), będąca przykładem sytuacji, w której system władzy i porządek społeczny ustanawiany jest przez starców. Gerontokracja ma prawo bytu wówczas, gdy nieliczne osoby dożywają starości i w efekcie tego mogą cieszyć się społecznymi przywilejami. Przeciwstawne podejście prezentuje gerontofobia, którą cechuje lęk przed starością i postrzeganie ludzi starych jako ciężaru społecznego. Źródeł takiego podejścia upatruje się w sytuacji, gdy ludzi starych i zniedołężniałych oraz słabych jest w społeczeństwie bardzo wielu i poprzez to stają się oni dla niego problemem ${ }^{7}$.

\section{Krótka charakterystyka starości}

Starość określana inaczej mianem trzeciego wieku bądź też późną dorosłością, stanowi końcową fazę życia człowieka, następującą po okresie młodości i dojrzałości. Specyficzne dla okresu starości są tzw. zdarzenia krytyczne, do których zalicza się: utratę zdrowia, kondycji i atrakcyjności fizycznej, utratę bliskich osób, statusu społecznego i ekonomicznego, poczucia przydatności i prestiżu, zbliżającą się perspektywę śmierci, a także przejście na emeryturę, opuszczenie domu przez ostatnie dziecko, wdowieństwo, chorobę i zmianę miejsca zamieszkania (przenosiny do dzieci lub do instytucji opiekuńczej) ${ }^{8}$.

Chociaż nie można w jednoznaczny sposób ustalić progu starości, to jednak można ją określić jako zespół komplementarnie ze sobą powiązanych zmian, o charakterze biologicznym, psychicznym, społecznym, a także duchowym. O zjawisku starzenia się można mówić wówczas, gdy wszystkie te zmiany są ze sobą sprzężone. Starość biologiczną można rozpatrywać, jako obniżenie sprawności fizjologicznej organizmu, a także jako bieg czasu biologicznego, uzależniony od czynników genetycznych, przyrodniczych, kulturowych oraz warunków pracy. Z kolei starość w wymiarze psychologicznym obejmuje zmiany w sferze

6 Por. J. Kracik, Być starym dawno temu..., dz. cyt.; O. Czerniawska, Starość wczoraj..., dz. cyt., s. 12-13.

7 J. Rembowski, Psychologiczne problemy starzenia się człowieka, Warszawa-Poznań 1984, s. 10.

8 Por. A. Grudziński, Zasadnicze wymiary starzenia się i starości - biologiczny, psychiczny i społeczny, w: Poznać, zrozumieć i zaakceptować starość, red. A. A. Zych, Łask 2012, s. 47-48; J. Stala, Osoba starsza a sens życia, w: Człowiek wobec bólu, cierpienia i śmierci, red. J. Stala, N. Bravená, Kraków 2013, s. 24-26. 
osobowości człowieka. Zmiany te ukierunkowane są przede wszystkim na zainteresowanie własną osobą. Starość społeczną należy natomiast rozpatrywać w kontekście utraty ról społecznych. Starość na płaszczyźnie duchowej może charakteryzować się większą wrażliwością na sprawy związane z religią oraz nadrabianiem zaległości życia duchowego 9 .

Na podstawie badań dotyczących potrzeb seniorów, które zostały przeprowadzone w skali całej Polski wyróżniono pięć obszarów problemowych, sprawiających osobom starszym największe trudności w codziennym funkcjonowaniu. Są nimi:

- Problemy ze zdrowiem - stanowią najczęściej wymienianą przez seniorów trudność dnia codziennego. Obejmują choroby ograniczające możliwość samodzielnego funkcjonowania w społeczeństwie, trudności w dostępie do opieki medycznej oraz wysokie ceny leków.

- Samotność i osamotnienie - wiążą się z osłabieniem kondycji psychicznej i mogą prowadzić do alienacji. Brak zainteresowania ze strony rodziny i najbliższego środowiska sprawia, że seniorzy wyłączają się z aktywnego życia, a w konsekwencji pogarsza się również ich stan fizyczny.

- Wykluczenie społeczne - wśród przyczyn wykluczenia badani wymieniali: trudną sytuację materialną, brak życzliwości i zrozumienia, trudności z dostępem do opieki medycznej, brak umiejętności posługiwania się nowymi technologiami oraz brak bliskich i przyjaciół.

- Zainteresowania i hobby - duża część seniorów stwierdziła, że ze względu na trudną sytuację finansową lub inne ograniczenia wynikające ze złego stanu zdrowia nie jest w stanie podjąć żadnych dodatkowych zajęć. Brak możliwości do podejmowania alternatywnych aktywności zgłaszały najczęściej osoby samotne lub zamieszkujące instytucje pomocowe.

- Konsultacje społeczne i udział w tworzeniu polityki lokalnej - prawie 60 proc. ankietowanych seniorów stwierdziło jednoznacznie, że nie ma wpływu na kreowanie polityki lokalnej. Ich zdaniem jest to rezultat zepchnięcia seniorów na margines życia społecznego, nie zaś brak chęci do udziału

9 A. Grudziński, Uniwersytety Trzeciego Wieku jako forma aktywności seniorów - analiza wybranych zagadnień, w: Sociální pedagogika v kontextu životních etap člověka, red. M. Bargel, jr., E. Janigová, E. Jarosz, M. Jůzl, Brno 2013, s. 1040-1041; Por. N. Pikuła, Etos starości w aspekcie społecznym. Gerontologia dla pracowników socjalnych, Kraków 2011, s. 11-42; A. Grudziński, Zasadnicze wymiary..., dz. cyt., s. 47-56; A. Grudziński, R. Spyrka-Chlipała, Młodość w służbie starości. Znaczenie praktyk studenckich w funkcjonowaniu wybranych domów pomocy społecznej w Krakowie, w: Starość może być atrakcyjna, red. N. Pikuła, Kraków 2012, s. 64; B. Szatur-Jaworska, P. Błędowski, M. Dzięgielewska, Podstawy gerontologii społecznej, Warszawa 2006; E. Trafiałek, Starzenie się i starość. Wybór tekstów z gerontologii społecznej, Kielce 2006; M. Straś-Romanowska, Późna dorosłość. Wiek starzenia się, w: Psychologia rozwoju człowieka. Charakterystyka okresów życia, t. 2, red. B. Harwas-Napierała, J. Trempała, Warszawa 2007; A. A. Zych, Leksykon gerontologii, Kraków 2007; K. Białożyt, Wielowymiarowy proces starzenia się i starości, w: Człowiek wobec bólu..., dz. cyt., s. 35-48. 
w takich przedsięwzięciach. Ponadto ponad 80 proc. wyraziło zainteresowanie udziałem w konsultacjach, gdyby tylko spotkania były realizowane. Znacząca większość badanych seniorów uważa jednocześnie, że władze nie liczą się z ich zdaniem ${ }^{10}$.

\section{Współczesna starość}

Prognozy demograficzne zakładają, że w 2020 roku osoby po 6o. roku życia będą stanowić blisko 25 proc. ludności polskiego społeczeństwa, a przygotowana przez Główny Urząd Statystyczny Prognoza ludności na lata 2008-2035 wskazuje, że najbliższe lata będą cechowały się przyrostem ludności w najstarszych grupach wiekowych. Szacuje się, że w roku 2030 liczba osób w wieku 85 lat i powyżej może sięgać nawet 800 tysięcy ${ }^{11}$.

Pomimo jednoznacznie brzmiących prognoz coraz częściej można zauważyć, że starość jest negowana, a także, że w świadomości społecznej istnieje wiele negatywnych stereotypów myślowych dotyczących ludzi starych. Można wręcz zaryzykować tezę, że epoka kulturowa, w której żyjemy boi się starości. Wiek sędziwy coraz częściej wiąże się ze wstydem i poczuciem zagrożenia.

Przemiany cywilizacyjne i zmiany społeczne podyktowane wpływami kultury popularnej przyczyniły się do ukształtowania „nowoczesnej tożsamości człowieka”. We współczesnym świecie nie ma ani miejsca na starość, ani czasu na to, żeby się zestarzeć, bowiem jest on zdominowany przez mass media, kult sukcesu, przyjemności, dobrobytu młodości i witalności ${ }^{12}$. Obowiązkiem współczesnego człowieka jest być młodym i pięknym. Tym samym, seniorzy we współczesnym świecie są akceptowani jeśli zachowują się jak młodzi ludzie i zwalczają oznaki starzenia się za pomocą wszelkich dostępnych im środków.

Zdaniem Jerzego Surdykowskiego w dzisiejszych czasach „młodość można kupić, a starość wyleczyć”. Z jednej strony pogoń współczesnego świata za młodością jest „gonitwą baranów ogłupionych przez reklamę”, a z drugiej stanowi efekt zapatrzenia w siebie, które stanowi nieodzowny element współczesnej cywilizacji ${ }^{13}$.

\footnotetext{
${ }^{10} \mathrm{~K}$. Zwolińska, Sytuacja społeczna osób starszych w polski społeczeństwie. Diagnoza na podstawie raportu końcowego projektu WŁĄCZwiek, w: Osoby starsze w społeczeństwie - społeczeństwo wobec osób starszych, red. M. Makuch, D. Moroń, Wrocław 2011, s. 160.

${ }^{11}$ M. Halicka, E. Kramkowska, Uczestnictwo ludzi starych w życiu społecznym, w: O sytuacji ludzi starych, red. J. Hrynkiewicz, Warszawa 2012, s. 33.

${ }^{12}$ J. Deręgowska, Współczesny człowiek wobec starości i nieuchronności przemijania, w: Edukacja do i w starości. Wybrane konteksty - problemy - uwarunkowania, red. M. Kuchcińska, Bydgoszcz 20o8, s. 25.

${ }^{13}$ J. Surdykowski, Starość, ,Znak” nr 622 (2007), s. 143.
} 
Idąc tym tropem można śmiało stwierdzić, że młodość jest jedną z podstawowych wartości współczesnego świata. Znaczna większość bohaterów seriali, czy reklam to ludzie piękni i młodzi. Z kolei osoby starsze częstokroć prezentowane są w mediach jako zależne, niedołężne, chore i marginalizowane ${ }^{14}$. Do takiego sposobu traktowania procesów starzenia się i starości przyczyniają się także stereotypy dotyczące ludzi starszych, na podstawie których można sądzić, że seniorzy są schorowani, niedołężni, nie mogą pracować i tym samym są pozbawieni środków utrzymania, wymagają stałej opieki i pielęgnacji. O osobach starszych mówi się także, że są osamotnione, konserwatywne, nietolerancyjne, a samej starości przypisuje się utratę sił seksualnych, bezużyteczność, obniżenie możliwości i osiągnięć ${ }^{15}$. Negatywny stereotyp starości skutkuje tym, że starzejący się ludzie postrzegają siebie tak, jak są dostrzegani i traktowani przez środowisko. Akceptują tym samym fakt zepchnięcia na margines społeczny, ograniczając swoje potrzeby ${ }^{16}$.

Z nieprzychylnymi postawami i negatywnym nastawieniem w odniesieniu do osób w podeszłym wieku, opartymi na stereotypach i uprzedzeniach dotyczących starości związany jest ageizm. Najczęściej definiuje się go jako „zespół stereotypów i uprzedzeń wobec grup wiekowych"17. W odniesieniu do ludzi w podeszłym wieku dotyczy on zarówno postaw, jak i działań wobec seniorów, a także norm i ról jakie przypisywane są ludziom ze względu na ich wiek. Źródeł ageizmu dopatruje się na wielu płaszczyznach. Jedną z nich jest niedostateczna wiedza ludzi młodych na temat faz życia. Innymi - gerontofobia, czy wreszcie zmiana modelu rodziny wielopokoleniowej na rodzinę nuklearną, składającą się z rodziców i dzieci, czego efektem jest osłabienie więzi między dziadkami i wnukami. W efekcie dziecko od początku nie integruje się z osobami w podeszłym wieku ${ }^{18}$.

$\mathrm{W}$ związku z tak zarysowaną sytuacją człowiek podejmuje różnego rodzaju próby ucieczki przed starością. W tym kontekście możemy mówić o:

- Ucieczkach lękowych, w których na pierwszy plan wysuwa się lęk ekonomiczny związany z niepewnością jutra. Starość, zwłaszcza w okresie zawirowań związanych z systemem emerytalnym, może jawić się jako niezasłużona kara, polegająca na braku środków finansowych do prowadzenia godnego życia. Konsekwencją takiego stanu często jest niepewność ekonomiczna jutra, lęk przed tym, że „nie wystarczy” na codzienne potrzeby.

\footnotetext{
${ }^{14}$ Zob. P. Gotfryd, Seniorzy w mediach, „Niebieska Linia” 4/57 (2008), s. 24.

${ }^{15}$ A. A. Zych, Leksykon gerontologii..., dz. cyt., s. 169.

${ }^{16}$ E. Trafiałek, Starzenie się i starość..., dz. cyt., s. 74.

${ }^{17}$ M. Grabowska, Ageizm - źródła i przejawy we współczesnym świecie oraz metody przeciwdziałania, w: Kompendium pielęgnowania pacjentów w wieku starczym, red. K. Kędziora-Kornatowska, M. Muszalik, Lublin 2007, s. 42.

${ }^{18}$ M. Grabowska, Ageizm..., dz. cyt., s. 43-44.
} 
Człowiek stary odczuwa także niepewność wynikającą z braku społecznego zrozumienia dla niedoborów związanych ze stanem fizycznym i psychicznym. Senior wycofuje się z życia, przestaje bywać w towarzystwie, chodzić na zakupy, załatwiać sprawy, ponieważ zamykając się w „skorupie” nie naraża się na lekceważenie czy pogardę.

- Ucieczkach konsumpcyjnych, związanych z tzw. „używaniem życia”, między innymi poprzez młodzieżowy styl bycia i ubierania, związki z młodszymi kobietami, używki, gry losowe i hazardowe, nałóg telewizyjny i internetowy. Wszystkie te zachowania stanowią formę ucieczki przed świadomością zbliżania się do nieuchronnego końca egzystencji. Za pozytywne przejawy ucieczek konsumpcyjnych należy uznać zwiedzanie kraju i świata, czy też uczestnictwo w życiu kulturalnym.

- Ucieczkach w praktyki religijne. Starość staje się często czasem renesansu życia religijnego, który z jednej strony może doprowadzić do jego pogłębienia, a z drugiej przybrać postać swoistej manii, mającej dewocyjny charakter. Aktywność religijna przygotowuje człowieka na sytuację starości i zbliżającej się śmierci, dając przy tym nadzieję i wiarę w rzeczywistość wykraczającą poza doczesność.

- Ucieczkach w pracę i nadaktywność. Praca wypełnia czas, przynosi zmęczenie domagające się odpoczynku i dzięki swojemu rytmowi odsuwa stawianie sobie pytań o zbliżający się kres życia ${ }^{19}$.

W czasach kultu młodości, starzejących się ludzi coraz częściej spycha się na margines życia społecznego i zawodowego, zamyka się w instytucjach opiekuńczych, a w ostateczności skazuje na samotność ${ }^{20}$. Współcześnie dominuje postawa społeczna, która niejako nakazuje traktować człowieka starego jako spauperyzowanego, pozostającego na marginesie życia emeryta, nie dotrzymującego kroku zmianom, jakie mają miejsce we współczesnym świecie, do którego młode pokolenia odnoszą się z politowaniem, a nawet $\mathrm{z}$ wrogością, czy niechęcią ${ }^{21}$. Często nie zauważa się, że starość zawiera w sobie ogromny potencjał. Podkreślał to Jan Paweł II pisząc o ludziach starszych: „Ludzie starzy pomagają nam mądrzej patrzeć na ziemskie wydarzenia, ponieważ dzięki życiowym doświadczeniom zyskali wiedzę i dojrzałość. Są strażnikami pamięci zbiorowej, a więc mają szczególny tytuł, aby być wyrazicielami wspólnych ideałów i wartości, które są podstawą i regułą

\footnotetext{
19 Por. H. Duda, Ucieczki od starości - próba analizy pojęć: poznać, zrozumieć i zaakceptować starość - na kanwie dawnej modlitwy, w: Poznać, zrozumieć..., dz. cyt., s. 39-45.

${ }^{20}$ Z. Szarota, Gerontologia społeczna..., dz. cyt., s. 7.

${ }^{21} \mathrm{~J}$. Nowicki, Historyczne uwarunkowania postrzegania roli człowieka starego $w$ społeczeństwie, w: Wybrane problemy osób starszych, red. A. Nowicka, Kraków 2008, s. 53.
} 
życia społecznego. Wykluczyć ich ze społeczeństwa znaczy w imię nowoczesności pozbawionej pamięci odrzucić przeszłość, w której zakorzeniona jest teraźniejszość. Ludzie starsi dzięki swej dojrzałości i doświadczeniu mogą udzielać młodym rad i cennych pouczeń" ${ }^{22}$.

Starość stanowi naturalny etap w życiu człowieka, jednak we współczesnym świecie coraz bardziej widoczny jest brak zgody na starzenie się. Swoisty kult młodości sprawia, że człowiek może się realizować pod warunkiem, że jest młody i ładny. Głównej przyczyny takiego stanu rzeczy należy upatrywać w lęku przed śmiercią. Starość jako etap ją poprzedzający traktowana jest jako zło konieczne, które za wszelką cenę należy odsunąć w czasie. Stąd też coraz powszechniejszy wśród osób zbliżających się do jesieni życia staje się youthahilizm, nazywany chorą obsesją młodości, który znajduje odzwierciedlenie w zabiegach odsysania tłuszczu, operacjach plastycznych, czy wstrzykiwaniu botoksu.

Takie podejście prowadzi do stopniowego wypierania starości z przestrzeni publicznej i patrzenia na nią przez pryzmat niewiedzy, stereotypów i uprzedzeń. Niezrozumienie tego, czym jest starość oraz brak jej akceptacji w sposób nieunikniony prowadzi do zgorzknienia i obrażania się na świat i otoczenie. Dlatego tak ważne jest ukazywanie pozytywnych aspektów starości, związanych z pełnieniem nowych ról społecznych w rodzinie, utrzymaniem zainteresowania światem zewnętrznym, czy relacjami towarzyskimi z rówieśnikami. Warto także zachęcać seniorów do aktywnego życia rodzinnego, społecznego, edukacyjnego, kulturalnego, rekreacyjnego, czy religijnego, w celu niwelowania odczucia izolacji i nieprzydatności społecznej.

\section{Proponowana literatura}

Białożyt K., Wielowymiarowy proces starzenia się i starości, w: Człowiek wobec bólu, cierpienia i śmierci, red. J. Stala, N. Bravená, Kraków 2013, s. 35-48.

Czerniawska O., Starość wczoraj, dziś i jutro, w: Ludzie starsi w trzecim tysiącleciu. Szanse - nadzieje-potrzeby, red. W. Wnuk, Wrocław 2002.

Deręgowska J., Wspótczesny człowiek wobec starości i nieuchronności przemijania, w: Edukacja do i w starości. Wybrane konteksty - problemy - uwarunkowania, red. M. Kuchcińska, Bydgoszcz 2008.

\footnotetext{
${ }^{22}$ Jan Paweł II, List Do moich Braci i Sióstr - ludzi w podeszłym wieku, Kraków 1999, nr 10.
} 
Duda H., Ucieczki od starości - próba analizy pojęć: poznać, zrozumieć i zaakceptować starość - na kanwie dawnej modlitwy, w: Poznać, zrozumieć i zaakceptować starość, red. A. A. Zych, Łask 2012.

Gotfryd P., Seniorzy w mediach, „Niebieska Linia” 4/57 (2008).

Grabowska M., Ageizm - źródła i przejawy we współczesnym świecie oraz metody przeciwdziałania, w: Kompendium pielęgnowania pacjentów w wieku starczym, red. K. Kędziora-Kornatowska, M. Muszalik, Lublin 2007.

Grudziński A., Spyrka-Chlipała R., Młodość w służbie starości. Znaczenie praktyk studenckich w funkcjonowaniu wybranych domów pomocy społecznej w Krakowie, w: Starość może być atrakcyjna, red. N. Pikuła, Kraków 2012.

Grudziński A., Uniwersytety Trzeciego Wieku jako forma aktywności seniorów - analiza wybranych zagadnień, w: Sociální pedagogika v kontextu životních etap člověka, red. M. Bargel, jr., E. Janigová, E. Jarosz, M. Jůzl, Brno 2013.

Grudziński A., Zasadnicze wymiary starzenia się i starości - biologiczny, psychiczny i społeczny, w: Poznać, zrozumieć i zaakceptować starość, red. A. A. Zych, Łask 2012.

Halicka M., Kramkowska E., Uczestnictwo ludzi starych w życiu społecznym, w: O sytuacji ludzi starych, red. J. Hrynkiewicz, Warszawa 2012.

Jan Paweł II, List Do moich Braci i Sióstr - ludzi w podeszłym wieku, Kraków 1999.

Kracik J., Być starym dawno temu, „Kontrapunkt” 39/40 (2000) nr 1/2.

Minois G., Historia starości. Od antyku do renesansu, Warszawa-Gdańsk 1995.

Nowicki J., Historyczne uwarunkowania postrzegania roli człowieka starego w społeczeństwie, w: Wybrane problemy osób starszych, red. A. Nowicka, Kraków 2008.

Pikuła N., Etos starości w aspekcie społecznym. Gerontologia dla pracowników socjalnych, Kraków 2011.

Rembowski J., Psychologiczne problemy starzenia się człowieka, Warszawa-Poznań 1984.

Stala J., Osoba starsza a sens życia, w: Człowiek wobec bólu, cierpienia i śmierci, red. J. Stala, N. Bravená, Kraków 2013.

Straś-Romanowska M., Późna dorosłość. Wiek starzenia się, w: Psychologia rozwoju człowieka. Charakterystyka okresów życia, t. 2, red. B. Harwas-Napierała, J. Trempała, Warszawa 2007.

Surdykowski J., Starość, „Znak” 622 (2007).

Szarota Z., Gerontologia społeczna i oświatowa. Zarys problematyki, Kraków 2004.

Szatur-Jaworska B., Błędowski P., Dzięgielewska M., Podstawy gerontologii społecznej, Warszawa 2006.

Trafiałek E., Starzenie się i starość. Wybór tekstów z gerontologii społecznej, Kielce 2006.

Zwolińska K., Sytuacja społeczna osób starszych w polski społeczeństwie. Diagnoza na podstawie raportu końcowego projektu WŁACZZwiek, w: Osoby starsze w społeczeństwie - społeczeństwo wobec osób starszych, red. M. Makuch, D. Moroń, Wrocław 2011.

Zych A. A., Leksykon gerontologii, Kraków 2007. 